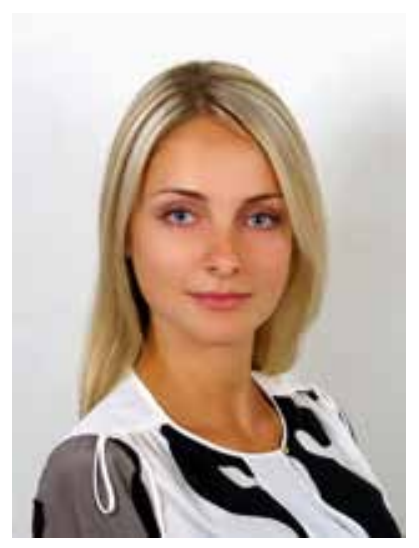

\author{
Анна Маслова, \\ кандилат юридичних наук, \\ Аоцент кафедри амміністративного та митного права \\ Університету митної справи та фрінансів
}

https://doi.org/10.32782/2020-38-05

УДК 349.2

\title{
Ефективність діяльності суб'єктів публічного адміністрування: адміністративно-правовий вимір
}

Постановка проблеми. Плюралістичність у поглядах на суть та призначення публічної адміністрації, iii структурний складник і системні характеристики, очевидно, має істотні наслідки для теоретичного осмислення та аналізу інших блоків проблематики, що загалом формують відповідний об'єкт наукового пошуку. Одним із важливих компонентів цих наукових досліджень є встановлення загалом одноманітних та однозначних критеріїв оцінювання результативності діяльності публічної адміністрації та інших суб'єктів публічного адміністрування, кількісних та якісних показників їх вимірювання.

Разом із тим досягнення і цього наукового завдання, з огляду на його важливий прикладний зміст, має спиратися на певний теоретичний фундамент, закладання якого слід починати iз визначення базових основ розуміння категорії «ефективність», узагальнення різноманітних підходів до теорії ефективності у праві та формулювання власного уявлення про зміст ефективності діяльності суб'єктів публічного адміністрування та її умов саме під кутом зору адміністративно-правової доктрини.

Мета статті - здійснити узагальнений огляд підходів до визначення ефективності діяльності суб'єктів публічного адміністрування та сформулювати власне бачення цього питання.

Аналіз останніх досліджень i публікацій та виклад основного матеріалу. На сучасному етапі розвитку суспільства термін «ефективність» вважається універсальним, оскільки його застосовують у всіх сферах людської діяльності [1, с. 137]. У енциклопедичних словниках слово «ефективність» (від лат. "effectus" - виконання, дія) розкривається як характеристика якого-небудь об'єкта (пристрою, процесу, заходу, виду діяльності), що відображає його суспільну користь, продуктивність та інші позитивні якості; у системах обробки інформації - швидкість обробки одиниці інформації, питомі витрати на обробку одиниці інформації; а слово «ефективний» - як такий, 
що приводить до потрібних результатів, наслідків, дає найбільший ефект; який викликає ефект (наприклад, ефективна доза опромінення) [2, с. 358]. У філософії під ефективністю розуміється здатність діючої причини зробити певний ефект, відзначається зв'язок ефективності зі свідомою діяльністю людей, підкреслюється, що ефективність являє собою ступінь близькості до дійсності «другого роду», що здійснюється людиною [3, с. 46-47].

C.В. Шахов, аналізуючи сучасні та ретроспективні дослідження феномена ефективності в праві, зокрема резюмує, що за допомогою методів загальної теорії права, соціології права, філософії права, окремих галузевих юридичних наук (у т. ч. адміністративно-правової) як предмет пізнання вченими розкривається суть та особливості ефективності права загалом [4; 5 ; 6; 7; 8; 9], ефективності законодавства [10; 11], правової норми $[12 ; 13 ; 14$; $15 ; 16 ; 17 ; 18 ; 19]$ (окремих різновидів адміністративно-правових норм [20; $21 ; 22]$, норм кримінального права [23], цивільно-процесуальних норм [24], норм цивільного права [25]), правового регулювання (у т. ч. й адміністративно-правового) [26; 27; 28; 29], механізму правового регулювання [30], методів права (наприклад, адміністративно-правових [31; 32; 33; 34]), правозастосовчої діяльності [35; 36; 37], реалізації норм права, у т. ч. й адміністративно-правових норм [38; 39], правотворчості [40] тощо [41, с. 168-169].

Детально не аналізуючи наявні підходи до вирішення порушеної проблематики, які існують у правовій доктрині, зазначимо, що загалом вчені-правники розкривають зміст указаної категорії крізь призму або ж цільового (співвідношення між метою права (його норм) і конкретними результатами ïi реалізації суб'єктами), або ж утилітарного уявлення про ефективність (настання передбачених позитивних правових наслідків вимірюється у співвідношенні
3 витратами часового, матеріального та організаційного ресурсу тощо), або ї комбінації (міра придатності права своєчасно у разі певних соціальних витрат викликати досягнення конкретного науково обгрунтованого позитивного результату).

Звісно, що ефективність у праві також розкривається й з інших аспектів, а окремі вчені цілком слушно порушують питання про комплексність категорії «ефективність» та необхідність їі різнобічного дослідження і не тільки під кутом зору названих вище аспектів. Зокрема, С.О. Жинкін зазначає, що ефективність перш за все можна розглядати в контексті виконання правом свого соціально-духовного призначення, яке реалізується через здійснення правом своїх функцій. Саме тому є сенс вести мову про регулятивну ефективність права, охоронну ефективність права, виховну ефективність права, ціннісну, загальнокультурну ефективність [42, с. 35]. На переконання С.О. Жинкіна, ефективність права - це успішне «обслуговування» ним суспільного розвитку, дієве регулювання соціального життя і психічних процесів, що супроводжують соціальне життя, як забезпечення правом спадкоємності соціально-культурних цінностей і разом із тим соціального, духовного, культурного, економічного та іншого динамізму [42, с. 35].

Разом із тим указаний вчений зауважує, що ефективність може бути також розглянута в широкому соціально-філософському сенсі як знаходження безпечного, такого, що постійно вдосконалюється, вигідного для окремих індивідів і суспільства загалом способу соціального існування людини. Таким чином, як правильно підкреслює правник, поняття «ефективність права» надзвичайно багатоаспектне, що повинно сприяти більш глибокому і повному розумінню цього соціального, психологічного та правового феномена [42, с. 35]. 
Своєю чергою C.I. Пунченко вказує, що ефективність права, іманентно включаючи соціальні характеристики, не обмежується ними, а має також спеціально юридичні, аксіологічні, психологічні, політичні, економічні аспекти, але саме соціальна ефективність є найважливішим різновидом ефективності права, що характеризує розвиток національного права в конкретний історичний період [8, с. 10]. На думку вченого, соціальна ефективність права можебути визначена у вузькому і широкому сенсах. У вузькому - це досягнення за допомогою правового впливу соціальних цілей, досягнення соціально значущих позитивних результатів за допомогою правових засобів, закріплених у законодавстві. У широкому - забезпечення за допомогою права соціально корисного і гармонійного існування особистості, соціальних, етнічних груп; забезпечення результативної взаємодії особистості, соціальних спільнот і суспільства загалом у рамках такого правопорядку; успішне здійснення за допомогою права соціально корисної активності за мінімізації неконструктивної громадської конфліктності [8, с. 10].

О.Д. Магденко, який приділяє увагу ефективності правових засобів, також порушує питання про багатоаспектність категорії «ефективність права». Так, на переконання вченого, по-перше, вона може бути розглянута як забезпечення за допомогою права ефективного, безперешкодного доступу до соціальних благ і їх обігу. По-друге, критерієм ефективності права як соціального регулятора може вважатися ускладнення суспільного життя, поява нових соціальних зв'язків та інститутів. По-третє, ефективність права в соціальному сенсі означає успішне, мінімально конфліктне функціонування наявних соціальних інститутів, наприклад сім'ї, трудових колективів, державного апарату, громадських об'єднань і т. д. По-четверте, під соціальною ефективністю права може матися на увазі максимальна згуртованість суспільства, його спрямованість за допомогою права на вирішення спільних завдань. По-п’яте, у разі розуміння норми як цінності вона буде вважатися ефективною, якщо закріплює і захищає прийняті духовні і соціальні цінності, зокрема порядок, свободу, власність, працю і т. д. По-шосте, у діяльнісному аспекті норма вважається ефективною, якщо максимально сприяє позитивній правовій активності, максимально перешкоджає антигромадській поведінці [43, с. 126-127].

Про комплексність ефективності норм адміністративно-деліктного права пише О.С. Рогачова, яка пропонує розглядати зазначену ефективність одразу в декількох аспектах, зокрема таких як:

1) цільовий аспект - це співвідношення між цілями норми адміністративно-деліктного права і реальними результатами їі застосування;

2) соціальний аспект ефективності норми адміністративно-деліктного права - це відповідність норми адміністративно-деліктного права соціальним інтересам. Він зумовлений правильним визначенням мети адміністративного стягнення, вибором його виду і змісту, спрямованого на зниження рівня соціально шкідливої конфліктності у сфері відносин щодо встановлення i застосування адміністративної відповідальності;

3) економічний аспект ефективності норм адміністративно-деліктного права виражається у забезпеченні економічної вигоди для держави норм адміністративно-деліктного права. Настання наслідків у вигляді призначення адміністративного стягнення повинне відбуватися 3 найменшими витратами організаційних, матеріальних, часових ресурсів;

4) психологічний аспект ефективності норми адміністративно-деліктного права виражається в тому, що вона впливаює перш за все на самого правопорушника, а також у тому, щоб 
через комунікативний устрій суспільних відносин за допомогою емоційних навантажень сформувати в інших осіб адекватну позицію щодо усвідомлення: вчиняти або не вчиняти ті чи інші адміністративно карані діяння. У зв'язку з цимпсихологічний аспект ефективності включає також ступінь формування у конкретних індивідів і їх груп активної громадянської позиції, бажання добровільно виконувати, дотримуватися, використовувати і застосовувати ті чи інші норми [44, с. 11-12].

Натомість цілком справедливе зауваження С.В. Шахова, що ефективність норм адміністративного права не обмежується запропонованими О.С. Рогачовою площинами, оскільки не менш важливим (особливо за сучасних умов) $є$ врахування також ціннісних та антропологічних характеристик результативності адміністративно-правового впливу. Варто зауважити, що сам С.В. Шахов, фокусуючи свою увагу на вказаних аспектах ефективності, переконує, що необхідним для визначення ефективності норми адміністративного права та права загалом є, з одного боку, визначення зв’язку між соціальною цінністю права та досягнутими результатами адміністративно-правового регулювання, а 3 іншого - аналіз співвідношення вказаних результатів з реальним станом реалізації адміністративно-правового статусу особи, забезпеченням, захистом iii прав та свобод та рівнем виконання нею обов'язків [41, с. 180-181]. Такий комплексний підхід дав змогу вченому сформувати власне бачення на ефективність адміністративно-правової норми з точки зору таких аспектів: людиноцентричного, економічного, політичного, психологічного, аксіологічного, цільового, утилітарного, поведінкового, конфліктного [45, с. 19-20].

Зазначимо, що досить близьким до предмета дослідження і О.С. Рогачової, і С.В. Шахова є наукові розробки В.В. Юровської, яка досліджує критерії ефективності методів адміністративного права. Вчена-адміністративіст підкреслює, «що ефективність методів адміністративного права слід розглядати у кількох аспектах, під кутом зору різних факторів впливу. Усі складники цього явища, кожний 3 яких, до речі, формує самостійну групу критеріїв ефективності, існують у нерозривній єдності між собою та дозволяють дати загальну оцінку рівню ефективності використання методів адміністративного права загалом або його окремих різновидів зокрема. Окрім того, необхідність застосування так би мовити комплексного підходу зумовлена ще й особливою сферою об'єктивізації методів адміністративного права - публічними відносинами. Саме у зв'язку з наведеним важливо, щоб мірила оцінювання методів адміністративного права відбивали одразу кілька площин сприйняття результативності (чи навпаки) адміністративно-правового регулювання та правового впливу норм адміністративного права» [46, с. 139]. На підставі вказаного В.В. Юровська вважає, що ефективність методів адміністративного права - це рівень їх регулюючого впливу на суспільні відносини, що формують предмет адміністративного права, який (рівень) визначається 3 урахуванням соціальних, політичних та економічних критеріїв [47, с. 154].

Про ефективність методів адміністративно-правового регулювання розмірковує й Ю.Ю. Чуприна. Основними критеріями ефективності методів адміністративно-правового регулювання у баченні вченої є: відповідність організаційної структури вимогам часу і меті; ступінь взаємозв'язків між керівництвом та персоналом; розподіл функцій між працівниками; норма керованості; частота дублювання повноважень та рівень конкуренції між працівниками або відділами; обізнаність персоналу щодо стратегіï, місії та цілей органів виконавчої влади; точність та 
актуальність визначення цілей; чіткість поставлених завдань; участь працівників удосягненніпоставленої мети; відповідність діяльності органів виконавчої влади поставленим цілям; визначеність контролю в органах виконавчої влади на інституційному рівні; здійснення контролю за основними напрямами діяльності; рівень колегіальності у прийнятті рішень; прогнозованість та актуальність розпоряджень органів виконавчої влади; рівень децентралізації стосовно прийняття рішень; підтримка вияву ініціативи з боку персоналу; процедура відбору кадрів; кадровий розвиток; процедура просування по службі; система оцінки показників діяльності; гордість за організацію роботи; ставлення до роботи; відносини по горизонталі; відносини по вертикалі; відносини між відділами; просування по службі та мотивація; відповідність рівня заробітної плати працівників їхнім очікуванням та реальному внеску; наявна в органах виконавчої влади система преміювання; система нематеріальних стимулів; відкритість та прозорість роботи органів виконавчої влади; рівень взаємозв'язків політичних партій та громадських організацій із керівництвом органів виконавчої влади; зв'язки органів виконавчої влади 3 представниками засобів масової інформації; стиль керівництва; доступ громадян до інформації з питань виконавчої влади на місцях (прозорість діяльності); налагоджена система служб та консультацій для громадян; участь у процесі прийняття рішень (відкритість); підтримка добровільних об'єднань громадян та неурядових організацій; рівень співпраці органів виконавчої влади та органів місцевого самоврядування (рівень виконання делегованих повноважень); врегулювання конфліктів між органами виконавчої влади та органами місцевого самоврядування [48, с. 187-188].

Але, як справедливо зауважує В.В. Юровська, запропоновані Ю.Ю. Чуприною критерії стосуються оцінювання діяльності публічного адміністрування загалом або його окремих суб'єктів і безпосереднього відношення до адміністративно-правового регулювання як такого не мають [46, с. 138]. Проте у контексті нашого дослідження вказаний підхід викликає інтерес та загалом заслуговує на підтримку, але з уточненням, що вказані мірила оцінювання ефективності все ж таки стосуються діяльності конкретного органу публічної адміністрації, а не адміністративно-правового регулювання.

Слід зауважити, що досить багато уваги різним аспектам ефективності приділяється представниками науки державного управління, які намагаються так само комплексно підійти до дослідження порушеної проблематики. Так, В.В. Цвєтков, який одним iз перших із вітчизняних дослідників почав формувати теорії ефективності державного управління, у своїх наукових працях, присвячених цій проблематиці, виділяв три поняття: економічну ефективність, цільову ефективність та організаційну ефективність. Економічна ефективність управління, за В.В. Цвєтковим, є результатом діяльності системи управління, що забезпечує досягнення мети, поставленої перед об'єктом управління, за найменших витрат, а цільова ефективність - узгодженість результату з метою [49, с. 37]. Організаційна ефективність - оптимальна форма взаємозв'язків елементів системи, яка робить їі найбільш ефективною в досягненні поставленої мети. Ця модель свідчить про те, що, хоча певні функціональні зв'язки можуть i задовольнити вимоги організації, однак деякі 3 них ефективніші ніж інші [49, с. 39]. Слід зауважити, що ефективність державного управління B.В. Цвєтков пов'язує із громадською свідомістю, з правовим становищем людини в суспільстві, виходячи з гіпотези, що: «ефективність державного 
управління - це людська специфіка управління, що здійснюється людиною і для людини» [49, с. 40].

А.Ю. Васіна, А.Ф. Мельник та О.Ю. Оболенський також виділяють три рівні ефективності, але вони дещо різняться від запропонованої вище моделі оцінювання. Так, на думку вчених, є загальна соціальна ефективність (рівень держави та всієї системи державного управління), спеціальна соціальна ефективність (ефективність функціонування суб'єктів державного управління), конкретна соціальна ефективність (ефективність діяльності управлінських органів і посадових осіб) [50].

В.Д. Бакуменко переконує, що ефективність державного управління це один з основних показників досконалості управління, що визначається за допомогою зіставлення результатів управління і ресурсів, затрачених на їх досягнення [51, с. 13]. На переконання О.А. Таньчук, оцінювання ефективності публічного управління $€$ систематичним актом аналізу процесу досягнення поставлених цілей і виконання функціональних завдань та визначення результатів діяльності державних інститутів, установ та органів місцевого самоврядування з метою підвищення їх ефективності [52, с. 69].

М.Д. Лесечко, демонструючи схожий із В.Д. Бакуменком підхід, пов'язує ефективність зі співвідношенням результатів і визначає її як нормований до затрат ресурсів результат дії або діяльності системи на певному інтервалі часу (відношення ефекту до затраченого ресурсу, різниця між ними, ефект за обмеженого ресурсу) [53, с. 221]. Поряд із цим М.Д. Лесечко вивчає два основні напрями ефективності: телеологічний (під ефективністю системи розуміється кількісно виражений позитивний вплив, який система вносить у функціонування надсистеми) та природно-науковий (передбачається введення фізично вимірюваного критерію ефективності на підставі постулату про фізичну природу зв'язків між системою і надсистемою) [53, с. 222].

Г.О. Сабадош та О.В. Харченко, вивчаючи зарубіжний досвід оцінки ефективності діяльності органів державної влади, доходять висновку, що «державні органи влади по всьому світу стикаються 3 необхідністю підвищення ефективності діяльності державних установ, яка впливає на поліпшення добробуту громадян. Щоб мати можливість вимірювання та контролю ефективності діяльності службовців підвідомчих державних органів, уряди цих держав запровадили системи іï моніторингу. Реалізація цього проєкту дала змогу не тільки відстежувати рівень ефективності того чи іншого державного органу, а й забезпечила синергетичний ефект від спільного спрямування зусиль різних державних органів на досягнення пріоритетних для країни показників» [54, с. 8]. Іншими словами, дослідники цілком слушно пов'язують ефективність публічного адміністрування із соціальним та економічним благополуччям населення, що повною мірою відповідає концепту людиноцентризму в діяльності публічної адміністрації як основи філософії їі функціонування.

Загалом, аналізуючи запропоновані вище підходи до розуміння ефективності публічного адміністрування та її складників, відзначимо, що більшість досліджень у цій сфері, як правило, оминає увагою відповідну систему оцінювання діяльності органів місцевого самоврядування. Хоча, як слушно зазначає О.С. Мороз, оцінка ефективності системи публічного управління, яка застосовувана у формах державного управління, місцевого самоврядування та управління громадськими організаціями, має окремі специфічні відмінності [55, с. 246].

Узагальнений огляд та контекстуальний аналіз окремих вищенаведених 
думок на природу ефективності публічного адміністрування свідчить про те, що загалом у фокусі уваги дослідників перебуває соціально-економічний вимір результативності діяльності публічної адміністрації із відповідними показниками економічного та суспільного характеру (майновий стан, рівень прибутку, фінансове становище, рівень безробіття, умови праці, якість адміністративних послуг та їх відповідність суспільним потребам тощо). Вкотре визнаючи правильність спрямування векторів дослідження природи публічної адміністрації на задоволеність інтересів людини та суспільства, відзначимо, що вибраний нами адміністративно-правовий ракурс вивчення порушеної проблематики зумовлює необхідність пошуку правових аспектів ефективності діяльності суб'єктів публічного адміністрування, зміст яких так само має охоплюватися потребами конкретної людини зокрема або суспільства загалом, але при цьому має відбивати рівень відповідності функціонування владних суб'єктів закріпленим у законодавстві правам та свободам особи у публічній сфері.

Висновки. Таким чином, ефективність публічного адміністрування в нашому уявленні має, безумовно, комплексний та багатогранний характер, контексти якого можуть мати економічний, безпековий, соціальний, психологічний, екологічний, правовий та інші ефекти. Своєю чергою адміністративно-правовий аспект ефективності публічного адміністрування дає змогу оцінити діяльність відповідних суб'єктів з точки зору їх здатності створити достатні умови для якомога повнішої реалізації приватною особою свого адміністративно-правового статусу у публічній сфері, наприклад, за рахунок високої якості адміністративних послуг, їх доступності, оптимальності організаційних умов відповідних адміністративних процедур, якості підзаконної нормотворчої діяльності та інших факторів.

\section{Список використаних джерел}

1. Джавадов Х.А. Отдельные аспекты имплементации понятия «эффективность» в понятийно-категориальный аппарат гражданского процесса. Часопис Київського університету права. 2014. № 4. С. 133-137.

2. Великий тлумачний словник сучасної української мови / уклад. і голова ред. В.Т. Бусел. Київ : Ірпінь, 2001. 1440 с.

3. Андрющенко М.Н. Понятие эффективности и его философский смысл. Уиеные записки кафедр общественных наук вузов г. Ленинграда. Серия «Философия». Ленинград, 1971. Вып. 12: Философские и социологические исследования. С. 42-53.

4. Лебедев М.П. Об эффективности воздействия социалистического права на общественные отношения. Советское государство и право. 1963. № 1. С. 22-31.

5. Пелевин С.М. Эффективность права и дальнейшее совершенствование законодательства о разводах. Правоведение. 1971. № 1. С. 95-104.

6. Лапаева В.В. Эффективность действия права. Проблемы общей теории права и государства : учебник / под. общ. ред. В.С. Нерсесянца. Москва, 2004. 612 с

7. Пунченко С.И. Социальная эффективность права в современной России (теоретический аспект) : дисс. ... канд. юрид. наук : 12.00.14. Краснодар, 2016. 169 с.

8. Пунченко С.И. Социальная эффективность права в современной России (теоретический аспект) : автореф. дис. ... канд. юрид. наук. Краснодар, 2012. 28 с.

9. Жинкин С.А. Эффективность права: антропологическое и ценностное измерение : дисс. ... докт. юридических наук : 12.00.01. Краснодар, 2009. 401 с.

10. Самощенко И.С., Никитинский В.И. Изучение эффективности действующего законодательства. Советское государство и право. 1969. № 8. С. 3-11.

11. Головченко В. Ефективність законодавства: проблеми оцінки та вимірювання. Юридичний вісник України. 2002. № 42(382). С. 9. 
12. Пашков А.С. Эффективность действия правовых норм / редкол.: Пашков А.С. (отв. ред.) и др. Ленингр. гос. ун-т им. А.А. Жданова, Науч.-исслед. ин-т комплексных социальных исследований. Ленинград, 1977. 143 с.

13. Кудрявцев В.Н., Никитинский В.И., Самощенко И.С., Глазырин В.В. Эффективность правовых норм : монография. Москва, 1980. 280 с.

14. Самощенко И.С., Никитинский В.И. О понятии эффективности правовых норм. Ученые записки ВНИИСЗ. 1969. Вып. 18. С. 164-168.

15. Фаткуллин Ф.Н., Чулюкин Л.Д. Социальная ценность и эффективность правовой нормы. Казань, 1977. 117 с.

16. Бонк Е.Л. Общественное мнение и эффективность правовой нормы : дисс. ... канд. юрид. наук : 12.00.01. Москва,1982. 215 с.

17. Жинкин С.А. Некоторые аспекты понятия эффективности норм права. Известия высших учебных заведений. Правоведение. 2004. № 1. С. 191-196.

18. Самощенко И.С., Никитинский В.И., Венгеров А.Б. К методике изучения эффективности правовых норм. Советское государство и право. 1971. № 3. С. $70-71$.

19. Козлов В.А. Вопросы теории эффективности правовой нормы : автореф. дис. ... канд. юрид. наук. Ленинград, 1972. 26 с.

20. Рогачева О.С. Эффективность норм административно-деликтного права : монография. Воронеж, 2011. 356 с.

21. Курагин Г.Г., Попов Л.Л. Факторы эффективности административно-правовых санкций. Правоведение. 1974. № 4. С. 37-45.

22. Худяков Е.А. Эффективность применения норм с административной преюдицией : учебное пособие. Москва, 1981. 34 с.

23. Нікітін Ю.В., Рощина I.О. Ефективність норм кримінального права України у попередженні злочинів : монографія. Київ, 2014. 168 с.

24. Чечот Д.М. Выявление эффективности некоторых гражданско-процессуальных норм с помощью социологических методов. Проблемы сощиологии права. Вильнюс, 1970. Вып. 1. С. $82-84$.

25. Илларионова Т.И. О категории эффективности гражданско-правовых норм. Гражданское право, эффективность и качество : межвузовский сборник научных трудов. / Под ред. О.А. Красавчикова. Свердловск, 1977. С. 70-78.

26. Пашков А.С., Чечот Д.М. Эффективность правового регулирования и методы ее выявления. Советское государство и право. 1965. № 8. С. 3-11.

27. Куракін О.М. Аналіз співвідношення категорії «ефективність правового регулювання» і суміжних понять. Актуальні проблеми вітчизняної юриспруденції. 2016. № 2. С. 7-10.

28. Байгутлин Р.И. К вопросу об эффективности правового регулирования (опыт аксиологического подхода к проблеме). Вестник Челябинского государственного университета. Серия «Право». 2008. № 31. С. 5-14.

29. Рибалко Н., Балабан С. Концептуальні засади визначення ефективності адміністративно-правового регулювання: міждисциплінарний підхід. Науковий часопис Національної академї прокуратури Украӥни. 2014. № 1. С. 147-159.

30. Абрамова А.А. Эффективность механизма правового регулирования : автореф. дисс. ... канд. юрид. наук. Красноярск, 2006. 27 с.

31. Шахов С.В. Стимул як елемент структури адміністративно-правової норми. Міжнародне та нащіональне законодавство: способи удосконалення : матеріали міжнародної науково-практичної конференції, м. Дніпро, 29-30 березня 2019 р. Дніпро, 2019. С. $101-104$.

32. Юровська В.В. Критерії ефективності методів адміністративного права. Тендениії та пріоритети реформування законодавства України : матеріали Всеукраїнської науково-практичної конференції, м. Херсон, 8-9 грудня 2017 р. Херсон, 2017. С. 80-83.

33. Юровська В.В. Ефективність методів адміністративного права: поняття та критерії оцінювання. Актуальні проблеми вітчизняної юриспруденції. 2017. № 6 . C. $150-155$. 
34. Чуприна Ю.Ю. Адміністративно-правові методи правового регулювання: сутність та зміст : дис. ... канд. юрид. наук : 12.00.07. Харків, 2016. 216 с.

35. Гусарєв С. Теоретичні проблеми методики визначення ефективності юридичної діяльності. Підприємництво, господарство і право. 2005. № 11. С. 60-63.

36. Лазарев В.В. Эффективность правоприменительных актов. (Вопросы теории). Казань, 1975. 208 с.

37. Перепелюк А.М. Механізм застосування права: структура та критерії ефективності (загальнотеоретичний аспект) : дис. ... канд. юрид. наук : 12.00.01. Київ, 2016. $224 \mathrm{c}$.

38. Рибікова Г.В., Колеснік М.В. Основні підходи до оцінки ефективності реалізації правових норм. Порівняльно-аналітичне право. 2014. № 8. С. 19-22.

39. Болокан І.В. Реалізація норм адміністративного права: проблемні питання теорії та практики : автореф. дис. ... докт. юрид. наук. Запоріжжя, 2017. 38 с.

40. Пугинский Б.И. Гражданско-правовые средства в хозяйственных отношениях. Москва, 1984. 224 с.

41. Шахов С.В. Норми адміністративного права: теоретико-правові аспекти ефективності : дис. ... докт. юрид. наук : 12.00.07. Дніпро, 2020. $441 \mathrm{c.}$

42. Жинкин С.А. Психологические проблемы эффективности права : монография. Санкт-Петербург, 2009. 376 с.

43. Магденко А.Д. К вопросу об эффективности правовых средств в механизме правового регулирования. Сборник статей Всероссийской научно-практической конферениии, посвященной 25-летнему юбилею Челябинского государственного университета, г. Челябинск, 24-26 мая 2016 г. Челябинск : Издательство ООО «Полиграф-мастер», 2016. C. $125-128$.

44. Рогачева О.С. Эффективность норм административно-деликтного права : автореф. дис. ... докт. юрид. наук. Воронеж, 2012. 50 с.

45. Шахов С.В. Норми адміністративного права: теоретико-правові аспекти ефективності : автореф. дис. ... докт. юрид. наук. Дніпро, 2020. 30 с.

46. Юровська В.В. Методи адміністративного права: теоретико-правові та праксеологічні аспекти : дис. ... докт. юрид. наук : 12.00.07. Запоріжжя, 2018. 428 с.

47. Юровська В.В. Ефективність методів адміністративного права: поняття та критерії оцінювання. Актуальні проблеми вітчизняної юриспруденції. 2017. № 6. C. $150-155$.

48. Чуприна Ю.Ю. Адміністративно-правові методи правового регулювання: сутність та зміст : дис. ... канд. юрид. наук : 12.00.07. Харків, 2016. 216 с.

49. Цвєтков В.В. Реформування державного управління в Україні: проблеми і перспективи / кол. авт. ; наук. кер. Київ : Оріяни, 1998. 364 с.

50. Васіна А.Ю., Мельник А.Ф., Оболенський О.Ю. Державне управління : підручник. Київ : Знання, 2009. 582 с.

51. Бакуменко В.Д. Формування державно-управлінських рішень: проблеми теорії, методології, практики : монографія. Київ : Вид-во УАДУ, 2000. 328 с.

52. Таньчук О.А. Основні підходи до оцінювання ефективності публічного управління. Вісник Національної академії державного управління при Президентові України. 2015. № 3. C. 63-71.

53. Лесечко М.Д. Основи системного підходу: теорія, методологія, практика : навчальний посібник. Львів : УАДУ, 2002. 300 с.

54. Сабадош Г.О., Харченко О.В. Проблеми адміністрування процесу вимірювання ефективності органів публічної влади в Україні. Державне управління: удосконалення та розвиток. 2018. № 7. С. 18-32.

55. Мороз О.С. Ефективність публічного управління у виконавчих органах місцевого самоврядування. Економіка і організащія управління. 2016. № 3 (23). С. 243-251. 


\section{Маслова А. Б. Ефективність діяльності суб'єктів публічного адміністрування: адміністративно-правовий вимір}

У статті здійснено спробу здійснити адміністративно-правовий вимір ефективності діяльності суб'єктів публічного адміністрування. На підставі узагальненого огляду та контекстуального аналізу окремих вищенаведених думок на природу ефективності публічного адміністрування встановлено, що загалом у фокусі уваги дослідників перебуває соціально-економічний вимір результативності діяльності публічної адміністрації із відповідними показниками економічного та суспільного характеру (майновий стан, рівень прибутку, фінансове становище, рівень безробіття, умови праці, якість адміністративних послуг та їх відповідність суспільним потребам тощо). Визнаючи правильність спрямування векторів дослідження природи публічної адміністрації на задоволеність інтересів людини та суспільства, відзначено, що вибраний у межах цього дослідження адміністративно-правовий ракурс вивчення порушеної проблематики зумовлює необхідність пошуку правових аспектів ефективності діяльності суб'єктів публічного адміністрування, зміст яких так само має охоплюватися потребами конкретної людини зокрема або суспільства загалом, але при цьому має відбивати рівень відповідності функціонування владних суб'єктів закріпленим у законодавстві правам та свободам особи у публічній сфері.

Доведено, що ефективність публічного адміністрування має комплексний та багатогранний характер, контексти якого можуть мати економічний, безпековий, соціальний, психологічний, екологічний, правовий та інші ефекти. Зауважено, що адміністративно-правовий аспект ефективності публічного адміністрування дає змогу оцінити діяльність відповідних суб’єктів з точки зору їх здатності створити достатні умови для якомога повнішої реалізації приватною особою свого адміністративно-правового статусу у публічній сфері, наприклад, за рахунок високої якості адміністративних послуг, їх доступності, оптимальності організаційних умов відповідних адміністративних процедур, якості підзаконної нормотворчої діяльності та інших факторів. суб'єкти.

Ключові слова: ефективність, критерії, показники, публічне адміністрування,

\section{Maslova A. Efficiency of public administration entities: administrative and legal dimension}

The article attempts to make an administrative and legal measurement of the effectiveness of public administration. Based on a generalized review and contextual analysis of some of the above opinions on the nature of public administration efficiency, it is established that in general the researchers focus on socio-economic dimension of public administration performance with relevant indicators of economic and social nature (property status, income level, financial situation, unemployment rate, working conditions, quality of administrative services and their compliance with social needs, etc.). Recognizing the correctness of the direction of the vectors of the study of the nature of public administration on the satisfaction of human interests and society, it is noted that the chosen within this study administrative and legal perspective of studying the issues necessitates a particular person in particular or society as a whole, but it should reflect the level of compliance of the functioning of government entities with the rights and freedoms enshrined in law in the public sphere.

It is proved that the effectiveness of public administration is complex and multifaceted, the contexts of which can have economic, security, social, psychological, environmental, legal and other effects. It is noted that the administrative and legal aspect of the efficiency of public administration makes it possible to assess the activities of relevant entities in terms of their ability to create sufficient conditions for the full realization of their administrative status in the public sphere, for example, due to high quality administrative services, their availability, the optimal organizational conditions of the relevant administrative procedures, the quality of by-laws and other factors.

Key words: efficiency, criteria, indicators, public administration, subjects. 